\title{
Theory and Design
}

\section{Biomedical Engineering Research at St. Petersburg State Electrotechnical University "LETI"}

\section{Z. M. Yuldashev}

St. Petersburg State Electrotechnical University (SPbSETU "LETI") is the oldest university in Russia in the field of electrical engineering. It is no coincidence that training in the medical and technical profiles started first in Russia at this university at 1962 [1]. Today SPbSETU trains engineers, and bachelors, masters, postgraduate, and doctoral students in the direction that is generally called "Biomedical engineering". And obviously, this training is not possible without the involvement of students, postgraduate, and doctoral students in research assisted by professors of the university.

This issue of Biomedical Engineering presents the results of research of the staff of the Biotechnical Systems (BTS) Department [2], which recently celebrated its fiftieth anniversary, and of the Electronic Devices (ED) Department, founded 75 years ago [3]. The BTS Department actively develops areas of biomedical engineering related to the development of medical information-measuring systems [4-7], processing, and analysis of biomedical information [8], modeling of biological processes and systems, information decision support for doctors, research of ergative systems, etc. [9]. The ED

St. Petersburg State Eletroctechnical University (LETI), St. Petersburg, Russia; E-mail: yuld@mail.ru
Department successfully developed new directions for Xray systems not only for biology and medicine, but also for other purposes [10].

These results, we hope, will provide great interest for readers.

We invite our colleagues to actively cooperate in the educational and scientific areas for further development of biomedical engineering, which is today a powerful factor increasing the efficiency of the national healthcare system.

\section{REFERENCES}

1. Z. M. Yuldashev and G. N. Pakhar'kov, Biotekhnosfera, No. 2, 26 (2012).

2. N. N. Potrakhov, Biotekhnosfera, No. 4, 42-46 (2013).

3. V. V. Shapovalov and A. B. Kubaichuk, Biotekhnosfera, No. 2, 713 (2012).

4. V. A. Orlov and V. V. Shapovalov, Biotekhnosfera, No. 2, 13-17 (2012).

5. L. M. Smirnova and Z. M. Yuldashev, Biotekhnosfera, No. 2, 1723 (2012).

6. Yu. I. Senkevich, Biotekhnosfera, No. 2, 24-30 (2012).

7. G. N. Pakhar'kov, Biotekhnosfera, No. 2, 37-43 (2012).

8. A. P. Nemirko, L. A. Manilo, and A. N. Kalinichenko, Biotekhnosfera, No. 2, 30-37 (2012).

9. P. I. Paderno, Biotekhnosfera, No. 2, 44-46 (2012).

10. N. N. Potrakhov and A. Yu. Griaznov, Biotekhnosfera, No. 3, 1823 (2009). 